\title{
Aerosol characteristics at a remote island: Minicoy in southern Arabian Sea
}

\author{
V Vinoj ${ }^{1}$, S K Satheesh ${ }^{1}$ and K Krishna Moorthy \\ ${ }^{1}$ Centre for Atmospheric and Oceanic Sciences, Indian Institute of Science, Bangalore 560 012, India. \\ ${ }^{2}$ Space Physics Laboratory, Vikram Sarabhai Space Centre, Trivandrum, India.
}

\begin{abstract}
Extensive measurements of aerosol optical and microphysical properties made at a remote island, Minicoy in southern Arabian Sea for the period (February 2006-March 2007) are used to characterize their temporal variability and Black Carbon (BC) mass mixing ratio. Large decrease in aerosol BC (from $\sim 800 \mathrm{ng} \mathrm{m}^{-3}$ to $\sim 100 \mathrm{ng} \mathrm{m}^{-3}$ ) was observed associated with change in airmass characteristics and monsoon rains. The total aerosol mass varied between $\sim 80$ and $20 \mu \mathrm{g} \mathrm{m}^{-3}$. Though the total mass fell drastically, a slight increase in super micron mass was observed during the June-August period associated with high winds. The mass fraction of Black Carbon aerosols during the prevalence of continental airmass is found to be $\sim 1.2 \%$ of the composite aerosols, which is much lower than the values reported earlier for this region.
\end{abstract}

\section{Introduction}

Aerosols form one of the major uncertainties in present climate change studies (IPCC 2001). The high spatio-temporal variability and limited measurements of aerosol physical and optical properties make it difficult to understand its impact on weather and hence on the climate. Their effect on incoming solar radiation is complicated due to high variability in their physical and optical properties. Quantifying and reducing the uncertainty in aerosol influences on climate is critical to the understanding of climate change (Bates et al 2006). Though there have been several experiments e.g., Indian Ocean Experiment (INDOEX) (Russel et al 1999; Ramanathan et al 2001), ACE-1, 2 and Asia, (Bates 1999; Russel and Heintzenberg 2000; Huebert et al 2003) conducted to study several different aspects of aerosol influences, they were mostly confined to some particular regions or seasons (small periods), which though give a better understanding on the aerosol properties, fail to quantify the seasonal variability. Moreover, investigations of aerosols over oceans are important from the stand point of understanding anthropogenic and continental impacts over oceans as well as in estimating the aerosol radiative forcing (e.g., Haywood and Shine 1997; Kaufman et al 2002; Moorthy and Babu 2006a).

In addition to this, it must also be noted that with the exception of soil dust, sea-salt forms one of the major contributors to the aerosol load especially over the oceans (Warneck 1998; Lewis and Schwartz 2004; Satheesh and Moorthy 2005) and hence cannot be ignored; further their interactions with the anthropogenic aerosols (like soot) will alter their effect on radiation. From INDOEX observations, Satheesh and Ramanathan (2000) suggested that the large aerosol surface forcing over the Indian Ocean region can influence the hydrological cycle in the tropics and has a far reaching impact on weather and hence on the climate. Babu et al (2004) showed that there occurs a large variability in BC mass fraction over the Arabian Sea region using ship-based measurements and discussed the implications to radiative forcing. Vinoj and Satheesh (2003) made aerosol optical measurements during the summer monsoon and showed enhanced aerosol load over the northern Arabian Sea region. They attributed this large loading to

Keywords. Marine aerosols; sea-salt aerosols; remote island; black carbon. 
the sea-salt aerosol generated due to high winds over the Arabian Sea. In addition, Satheesh et al (2006) showed large spatio-temporal variability in aerosol characteristics over the Arabian Sea region. Eck et al (2001), from observations made during (January to June for three years 1998 to 2000) at Kashidhoo, an island in the Maldives territory showed large interannual variability in the aerosol characteristics. Moorthy and Satheesh (2000a) carried out extensive aerosol optical measurements at Minicoy for the period 1995 to 1996 and showed the seasonality and wind speed dependence. With the exception of this study, there seems to be very little knowledge on aerosol seasonality over this region especially during monsoon season (June to September). Moreover, continuous all season measurements of aerosol BC and composite aerosol is lacking especially over the ocean in this region.

Minicoy Island in the southern Arabian Sea, due to its location being far from the continental influence and lack of any local industrial activity forms an ideal location for aerosol studies. In this paper, we report the optical and microphysical measurements carried out at the island for a period of over one year from February 2006 to March 2007.

\section{Minicoy Island: Physical features}

Minicoy $\left(8.3^{\circ} \mathrm{N}, 73.04^{\circ} \mathrm{E}\right)$ is one of the eleven inhabited islands of the Lakshadweep island chain and the farthest of all other islands in southern Arabian Sea. The closest island (Kalpeni) of the Lakshadweep chain is $\sim 183 \mathrm{~km}$ away from Minicoy. This tiny crescent shaped island situated at the southern tip of the Lakshadweep archipelago has a surface area of $\sim 4.4 \mathrm{~km}^{2}$. The north-south oriented island with a length of $\sim 10 \mathrm{~km}$, and the widest point being $\sim 800 \mathrm{~m}$ has a population of $\sim 9500$ (2001 Census). The small size of the island, devoid of any industrial or urbanlike activity thus provides an ideal, clean marine platform for aerosol measurements on a long term basis (for more details, see Moorthy and Satheesh 2000a).

\section{General meteorological conditions}

Minicoy Island due to its tiny size with negligible landmass does not respond to the diurnal changes in solar heating to drive meso-scale circulations (Moorthy and Satheesh 2000a). Consequently, the prevailing winds are those associated with the synoptic circulation of the region (monsoon). The wind pattern over the island is largely seasonal, with north-westerlies/westerlies during April to
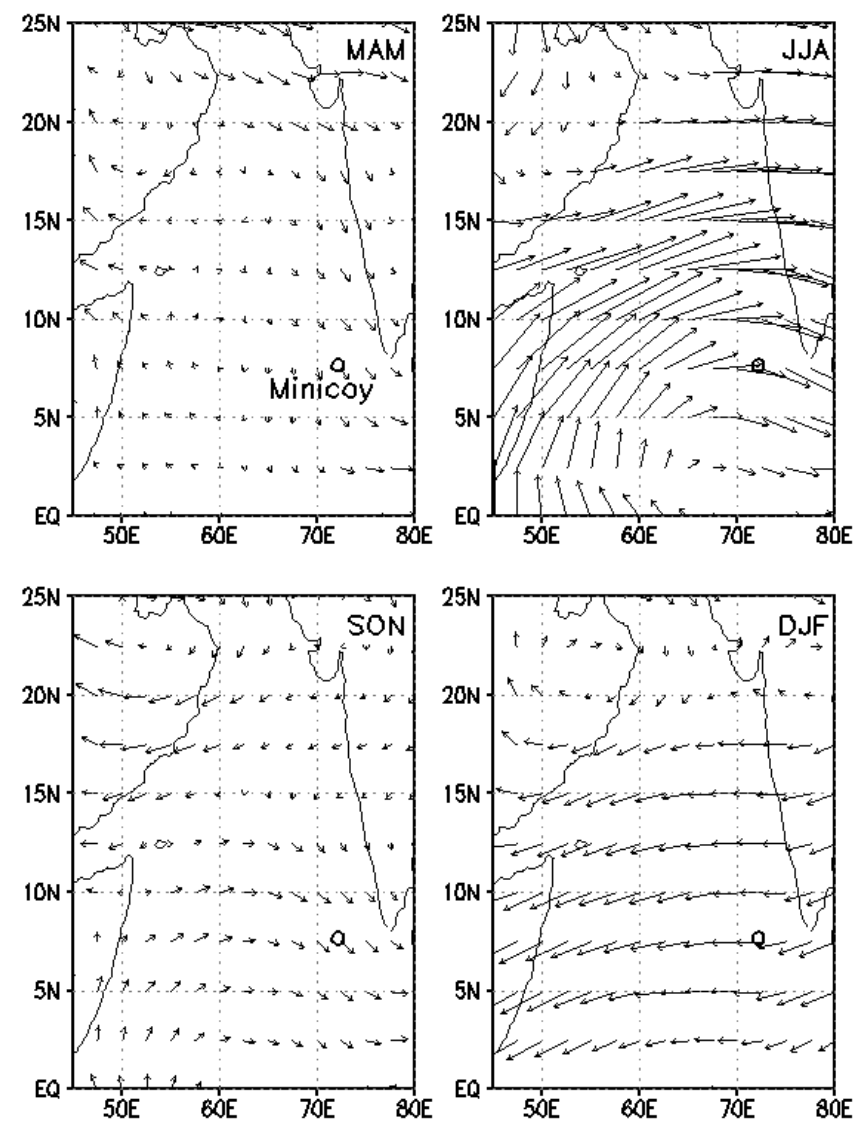

Figure 1. Wind vector during pre-monsoon (MAM), summer monsoon (JJA), post-monsoon (SON) and winter (DJF) over southern Indian region along with the island location. Also marked is the location of Minicoy Island.

October, changing to north-easterlies/easterlies for the rest of the year.

Figure 1 shows the spatial pattern of seasonally changing winds over the Arabian Sea region during 2006. The most striking feature is the high wind speeds during June-August (JJA) period associated with the south-west monsoon, with winds mostly from oceanic regions. This is the period, when the airmass trajectory is mostly over the oceanic regions and is not influenced by major anthropogenic activities; hence the aerosols are expected to be purely marine in nature. The winds are normally very strong during this period (instantaneous values as high as 15 to $20 \mathrm{~m} \mathrm{~s}^{-1}$ are observed). The December to February (DJF) period is characterized by winds mostly from the Indian subcontinent, which is expected to have large anthropogenic signature. March to May (MAM) and September to November (SON) can be said to be the transition periods between summer (purely marine) and winter (largely anthropogenic). Further, the winds from north of Arabian Sea might be influenced by dust from the Saudi Arabian desert region during 

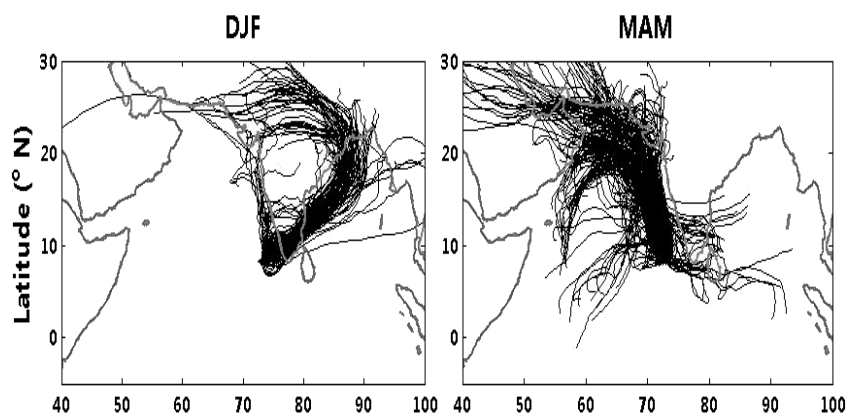

JJA
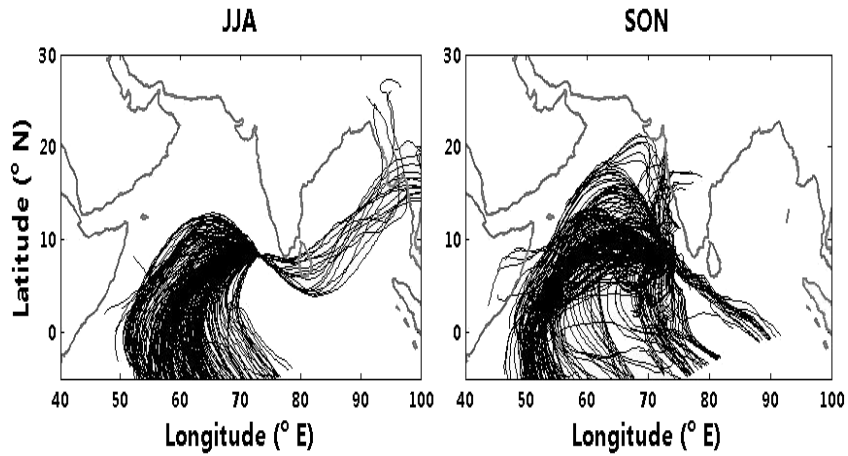

Figure 2. The back trajectories terminating at Minicoy during different seasons, pre-monsoon (MAM), summer monsoon (JJA), post-monsoon (SON) and winter (DJF) (500 $\mathrm{m}$ above ground level).

MAM (Moorthy and Satheesh 2000b). Figure 2 shows the airmass back trajectories terminating at Minicoy during different periods thereby, clearly showing the seasonal change in aerosol source regions (see section 5.2 for details of the back trajectory calculation). Hence, by making long term measurements of aerosol characteristics from a single location in the southern Arabian Sea (Minicoy), it is possible to study purely marine, anthropogenic as well as dust aerosols.

\section{Experimental setup}

The aerosol optical and microphysical measuring instruments were installed at India Meteorological Department's (IMD) meteorological observatory at Minicoy. The aerosol observation station was established during mid February as a long term observational platform as part of the ISROGBP (Indian Space Research Organization's Geosphere Biosphere Program) network as well as to provide the additional intensive observational support over the southern Arabian Sea region for the Integrated Campaign for Aerosols and Radiation Budget (ICARB) experiment (Moorthy et al 2006b) carried out from February to May 2006.

The aerosol optical and microphysical measurements were made continuously since February
2006 till March 2007. The aerosol optical depth (AOD) measurements were made using a Multi Wavelength Radiometer (MWR) designed and developed at Space Physics Laboratory (SPL) following the principle of filter wheel radiometers (Shaw et al 1973; Moorthy et al 1997, 1999) The MWR measures the field limited direct solar flux at 10 different channels centered at 380, 400, 450, $500,600,650,750,850,945$ and $1025 \mathrm{~nm}$ with full width half maximum (FWHM) band at the range of 6 to $10 \mathrm{~nm}$ at different wavelengths as a function of solar zenith angle. The field of view of the instrument is limited to $\sim 2^{\circ}$ using lens pin-hole detector optics, so that the effect of diffuse radiation entering into the system field of view on the retrieved optical depths is insignificant. For more information on retrieval technique used and error analysis of this instrument see Moorthy et al (1997, 1998). The major advantage of this instrument is its unattended operation once it is set to track the sun mechanically.

AOD was also measured using a hand held Microtops sun photometer at five different wavelengths centered at $340,380,500,675$, and $870 \mathrm{~nm}$ with an FWHM bandwidth of 2 to $10 \mathrm{~nm}$ at different wavelengths. The field of view of this instrument is $\sim 2.5^{\circ}$. The accuracy of the measured AOD is $\sim 0.02$ at $500 \mathrm{~nm}$. MWR was operated from February 2006 to July 2006; thereafter Microtops sun photometer was used from November 2006 to March 2007. Aerosol optical depth measurements were made whenever clear sky conditions prevailed. Special care was taken to avoid any contamination due to very thin clouds, wherein observations were made only when the sun's disc was clear of any clouds and the nearest cloud was sufficiently away from the sun disc. More details about Microtops sun photometer are available elsewhere (Morys et al 2001; Porter et al 2001; Ichoku et al 2002).

Aerosol BC mass concentrations $\left(\mathrm{ng} \mathrm{m}^{-3}\right)$ were measured continuously with an AE-2 tape Aethalometer (Magee Scientific). The instrument measures attenuation of light transmitted through the aerosols accumulated on a quartz fiber filter that acts as a perfect diffuse scattering matrix with light absorbing particles embedded in it (Hansen et al 1984; Hansen 1996). The ambient air was drawn from a height of $3 \mathrm{~m}$ above the ground. The instrument was operated at a flow rate of 4 to 6 liters per minute and a data averaging time of 15 to 30 minutes depending on the aerosol loading. Low flow rates and low averaging times were not used in this location as the measurable BC mass was very low. The instrument was operated with a $10 \mu \mathrm{m}$ sharp cut cyclone at the air intake part of the inlet tube. Field experiments have shown good agreement between the aethalometer measured $\mathrm{BC}$ 
mass and other analytical and thermal techniques (Im et al 2001). The instrument has been factory calibrated and errors in the measurements are $+/-10 \%$.

The size segregated aerosol mass concentration was measured using a GRIMM dust monitor model 1.108. This instrument is a small portable unit, used for the continuous measurement of particles in the air (aerosols). The ambient air to be analyzed is drawn into the unit via an internal volumecontrolled pump at a rate of 1.2 liters/minute. These measurements are determined in one of two basic modes, particle counts as counts/liters or mass as $\mu \mathrm{g} \mathrm{m}^{-3}$. We have operated the instrument in the mass mode. These measurements were reported for 15 size distribution channels from 0.23 to above $20 \mu \mathrm{m}$. The model 1.108 uses a lightscattering technology for single-particle counts, whereby a semiconductor-laser serves as the lightsource. The scattered signal from the particle passing through the laser beam is collected at approximately $90^{\circ}$ by a mirror and transferred to a recipient-diode. The signal of the diode passes a multi-channel size classifier after a corresponding reinforcement. A pulse height analyzer then classifies the signal transmitted in each channel.

Normally, marine aerosols are hygroscopic and grow to large sizes at high ambient relative humidities, which increases their scattering coefficients (Charlson et al 1984; Hegg et al 1993). In the present experiment, we have used a system for dehumidification in GRIMM dust monitor, whereby clean dry air is brought into the sample pipe in fixed ratio which assures that, there is no condensation and hence no growth. Minicoy being a marine island location, we set the relative humidity threshold at $70 \%$ so that the dehumidification system is almost always operational.

\section{Result and discussion}

\subsection{Aerosol optical depth}

The monthly mean variation of aerosol optical depth at $500 \mathrm{~nm}$ is shown in figure 3. Large variability in aerosol optical depth is observed between different months. The observed monthly mean AOD values were as high as $\sim 0.5$ in February and July and as low as $\sim 0.15$ during the October/ November months (see figure 3 ).

Aerosol optical depth measurements from satellite instruments like MODIS have been found to have significant correlation with the groundbased and ship-based observations over the oceanic regions (Remer et al 2002; Vinoj et al 2004). Measurements of aerosol optical depth during the peak monsoon period (July to October) were not made

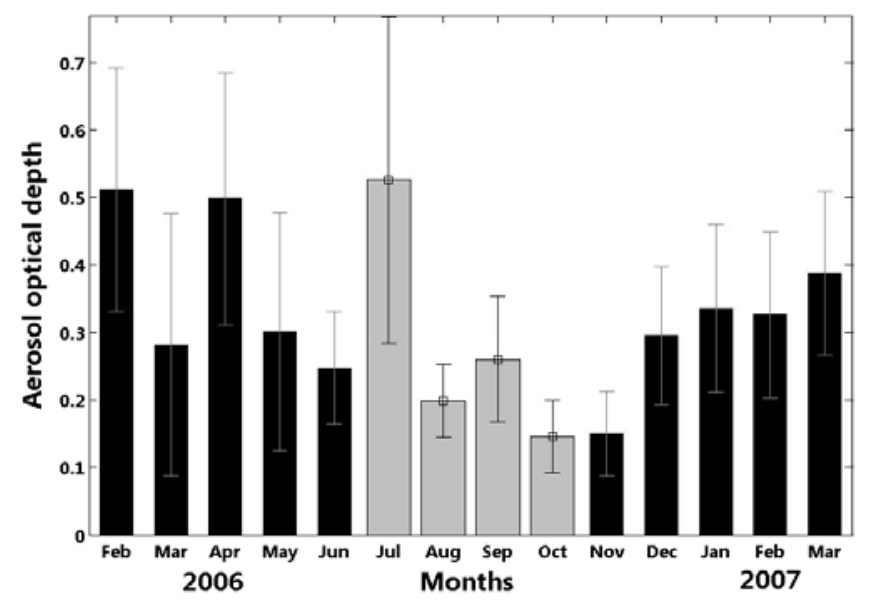

Figure 3. The monthly mean variation of aerosol optical depth at Minicoy (February 2006 to March 2007), the error bars represent the standard deviation. The square symbols indicate MODIS AQUA satellite data.

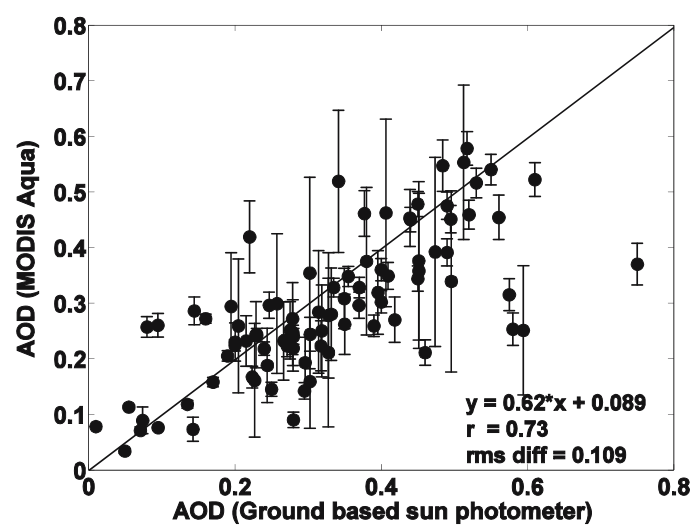

Figure 4. Scatter plot between ground based and MODIS AQUA satellite aerosol optical depth. The error bars represent the standard deviation for ground-based observation.

due to some technical difficulties and logistical constraints. A scatter plot (figure 4) of groundbased aerosol optical depth measurement with the corresponding values derived from MODIS AQUA satellite shows good agreement with a root mean square difference of 0.109 . This agreement provided us the validation of the satellite data. Hence we used the daily mean level 3 MODIS AQUA satellite data $(1 \times 1$ degree resolution AOD at $550 \mathrm{~nm})$ to determine the monthly mean during periods with no AOD data (July to October) to study the aerosol variability. In figure 3 , the bar graph with square symbol denotes the use of satellite data in determining the monthly mean.

It must be stressed that the AOD being a column integrated measurement may be influenced by changing aerosol characteristics over the whole atmospheric column, whereas the BC and composite aerosol mass are surface measurements 


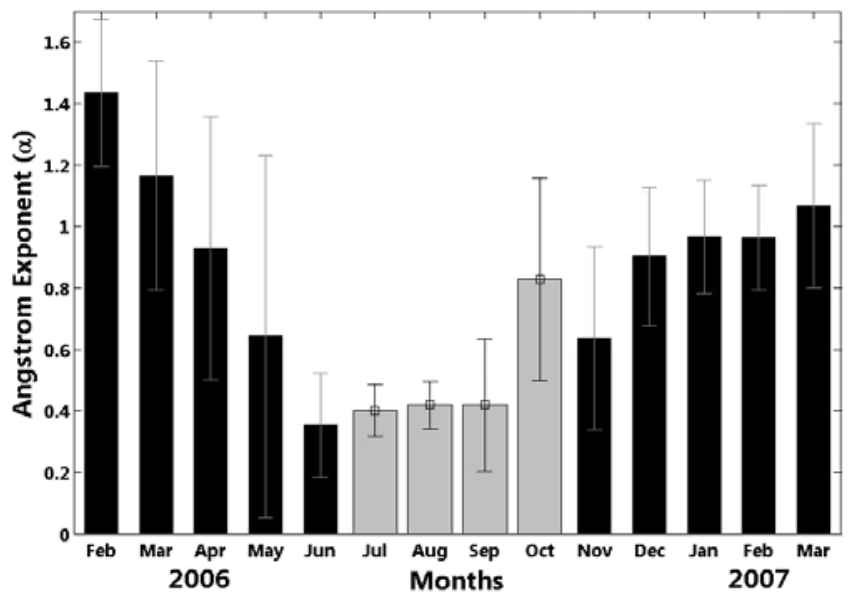

Figure 5. The monthly observed Angström wavelength exponent at Minicoy (February 2006 to March 2007), the error bars represent the standard deviation. The square symbols indicate MODIS AQUA satellite data.

and hence reflect the boundary layer aerosol characteristics.

The spectral distribution of aerosol optical depth contains information about aerosol size distribution. The simplest way to describe aerosols size distribution is by using Angström power law given by

$$
\tau_{a \lambda}=\beta \lambda^{-\alpha}
$$

where $\tau_{a \lambda}$ is the aerosol optical depth at wavelength $(\lambda), \alpha$ is the wavelength exponent, $\beta$ is the turbidity parameter and $\lambda$ is the wavelength in $\mu \mathrm{m}$. The value of $\alpha$ depends on the ratio of concentration of large to small aerosols and $\beta$ represents the total aerosol loading in the atmosphere (Shaw et al 1973). The anthropogenic aerosols being produced mostly by the gas to particle conversion processes are in the sub-micron size range whereas, natural aerosols like sea-salt and dust being produced by mechanical disintegration processes are coarse particles. This information, along with the spectral dependence of aerosol optical depth gives an insight into the source of aerosols.

The Angström wavelength exponent has been calculated using the spectral aerosol optical depth in the wavelength interval of 380 to $850 \mathrm{~nm}$. This was done for consistency between different instruments used in the study. However, MODIS AQUA satellite provides Ångström wavelength exponent corresponding to the spectral region 550 to $860 \mathrm{~nm}$. Figure 5 shows the monthly mean Ångström wavelength exponent for Minicoy, it can be seen that irrespective of the random nature of aerosol optical depth (figure 3), Angström wavelength exponent shows a very clear pattern. The sharp fall in $\alpha$ from about $\sim 1.4$ to $\sim 0.4$ clearly indicates a fall in anthropogenic impact from the Indian

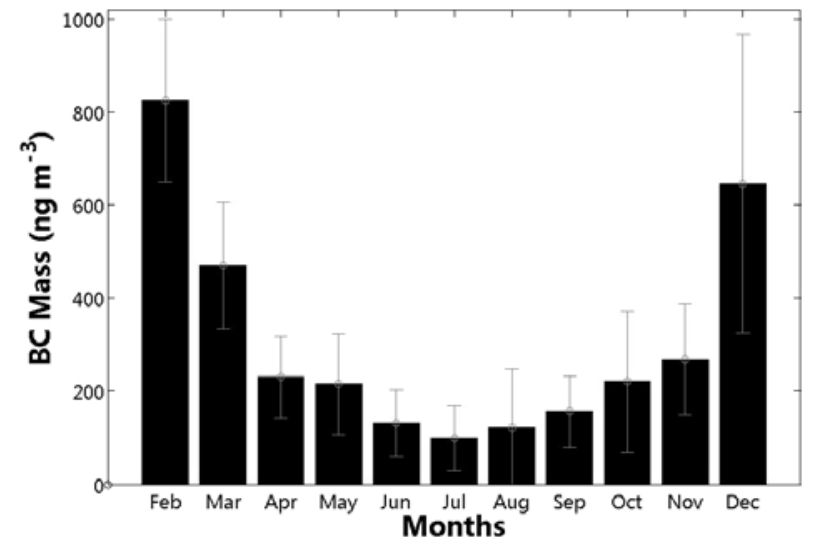

Figure 6. The monthly mean Black Carbon variation with standard deviation at Minicoy in southern Arabian Sea.

subcontinent especially during February through June and the revival during November to December period.

\subsection{Black Carbon aerosol}

The aerosol BC or soot is mainly a byproduct of incomplete combustion of fossil fuel burning. Due to its absorption of solar radiation in the visible and near infrared region of the spectrum BC compliments other green house gases (GHG) in heating the atmosphere. Figure 6 shows the monthly mean BC mass concentration observed at Minicoy. The thin lines overlaid on the bar chart are the monthly standard deviation of BC. It can be seen that there is large seasonal variation of $\mathrm{BC}$ mass at Minicoy. Being a pristine island with negligible anthropogenic activity, the only possible reason for the large variation in $\mathrm{BC}$ mass is the changing airmass characteristics associated with the wind pattern over the region (see section 3 for details). Though there were large day-to-day fluctuations in the measured $\mathrm{BC}$ mass concentration, they were super posed on a more regular seasonal variation.

The largest monthly mean values observed were $\left(\sim 800 \mathrm{ng} \mathrm{m}^{-3}\right)$, during the winter (December to February). Summer (June to August) shows a drastic fall by a factor of ( $\sim 6$ to 7$)$. This drastic decrease could be attributed to two factors of which the most important is the change in airmass characteristics. Winter is characterized by winds mainly from the continental regions, where pollution from fossil fuel combustion is more prevalent. The second important factor is the washout by rain associated with the arrival of monsoon (June to September) in the island. The BC mass concentration recovers to its winter value steadily from August through December. Previous studies though confined to the winter period to understand the source regions of aerosol origin during Indian 


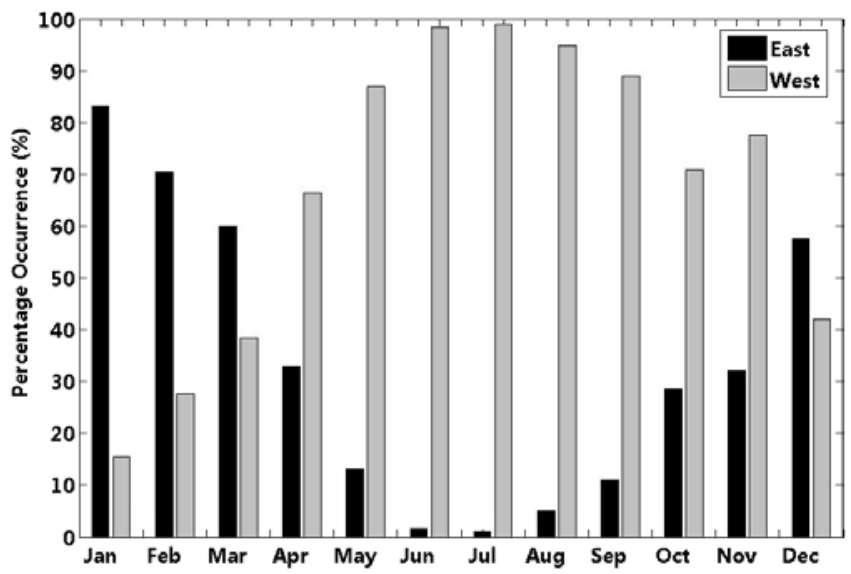

Figure 7. The percentage occurrence of winds from east and west of north at Minicoy (data from Moorthy and Satheesh 2000).

Ocean Experiment intensive field phase (INDOEXIFP) (January to March 1999) have identified, several regions like Indo-Gangetic Plain, central India, south India, Africa, west Asia and north west India that have a large influence on the aerosol characteristics over the Indian Ocean region (Verma et al 2007). Previous studies using satellite data and models have shown that south Asia and the Indian subcontinent region are major contributors to the aerosol loading over the Indian Ocean region (Nair et al 2003; Reddy et al 2004). The BC mass reported for Port Blair in Andaman and Nicobar Islands in the Bay of Bengal to the east of Indian landmass, was higher than those observed at Minicoy. During winter, the measurements at Port Blair were comparable to values reported over continental locations though lower than those reported over urban locations (Moorthy et al 2006a). They attributed these higher values mostly to the long range transport as well as local source. The lowest values of $\mathrm{BC}$ mass concentration during the summer at Minicoy were comparable to the values reported for remote and pristine oceanic locations $\left(<100 \mathrm{ng} \mathrm{m}^{-3}\right.$ ) (Andreae et al 1984; Cachier et al 1986; Clarke 1989; Bodhaine 1995).

Figure 7 shows the percentage occurrence of winds from east and west of the island (data from Moorthy and Satheesh 2000a). From figure 1, it is evident that airmass reaching the island from west of north are mostly from the northern Arabian Sea and the Indian Ocean region, whereas the winds from east of north, mostly originate over Indian landmass and the Bay of Bengal. The monthly mean $\mathrm{BC}$ mass clearly follows the pattern of winds from east of north (see figure 7) showing the continental influence in modulating the anthropogenic aerosol characteristics over southern Arabian Sea. The above discussion in conjunction

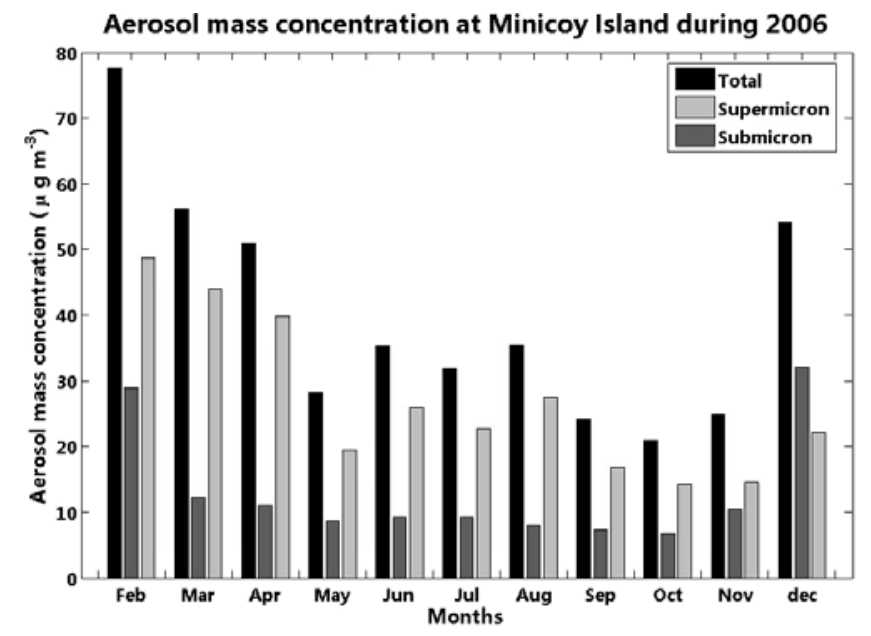

Figure 8. The monthly mean total, super micron and submicron aerosol mass concentration observed at Minicoy.

with trajectories terminating at Minicoy shown in figure 2 shows clearly the seasonal change in source regions of aerosols reaching the island. The trajectories were calculated for every six hours at $500 \mathrm{~m}$ height (AGL, above ground level) using HYbrid Single Particle Lagrangian Integrated Trajectory (HYSPLIT 4) Model (Draxler 1999).

\subsection{Total aerosol mass}

The GRIMM aerosol mass spectrometer gives aerosol mass distribution at 15 size bins ( 0.23 to greater than $20 \mu \mathrm{m})$. Total mass is obtained as cumulative sum of aerosol mass at each size bin. The GRIMM mass spectrometer gives the total mass of aerosols greater than $0.23 \mu \mathrm{m}$ size.

The total mass using the 15 size bin mass spectrometer also shows variation similar to $\mathrm{BC}$ with a fall from winter (DJF) to summer (JJA). BC falls off rapidly, but the total mass concentration though supplementing the observation, doesn't fall as rapidly as $\mathrm{BC}$ (figure 8). The total mass falls $\left(\sim 80\right.$ to $\left.\sim 30 \mu \mathrm{g} \mathrm{m}^{-3}\right)$ from February to July, and the reason could possibly be that, though the anthropogenic aerosol load has decreased considerably, the production of sea-salt aerosols due to the high winds along with the long airmass trajectory over the ocean (see figure 1), collect sufficient seasalt aerosols to replenish the fall created by the loss of continental influence. It must also be noted that the BC mass is only a subset of the total aerosol mass measured. The monsoon (June to September) period is characterized by widespread rains over the Indian landmass, the wet deposition of aerosols due to rains over the source regions (e.g., Indian landmass) can also contribute to the fall in $\mathrm{BC}$ as well as total aerosol mass at the island, where it is transported. It can be said that the fall in $\mathrm{BC}$ and 
total aerosol mass could be due to the change in airmass characteristics and washout due to rains, both over the source regions as well as over the island.

We have further sub-divided the measured aerosol mass into submicron $(<1 \mu \mathrm{m})$ and super micron $(>1 \mu \mathrm{m})$ particles in order to better understand the seasonality described in the previous sections. Figure 8 shows the monthly mean variation of total, super micron and submicron aerosols. The submicron aerosol shows a drastic (step) decrease during February to March and a drastic increase during November to December, but shows a fairly gradual fall towards the peak monsoon months (June-July). The airmass originating over Indian regions shows a larger fraction of submicron aerosols (mostly during December to February). The short path distance covered by aerosols of continental origin over the oceans clearly leaves the continental imprint on the aerosol characteristics with large submicron aerosol fraction to the composite aerosol mass.

March/April and October/November being the transition periods for the airmass between mostly continental and purely marine show low submicron fraction, though the airmass would have traveled over the continental region in equal proportions in time. This could be because, the aerosols due to longer travel over the oceans are perhaps aged and grown due to mixing (coating) of sea-salt with the continental aerosols having larger sizes and hence lower submicron aerosol fraction.

Aerosols over oceans are either produced locally or transported from sources elsewhere. The major source of aerosol over the ocean is sea-salt. These particles are generated by various physical processes, especially the bursting of the entrained air bubbles during the white cap formation (Blanchard 1963, 1983; Monahan et al 1986), which are mostly dependent on wind speed over the ocean surface. The sea-salt is the principle constituent of the coarse particle mode except during episodes of continental dust transport. Moreover, winds in excess of $\sim 3 \mathrm{~m} \mathrm{~s}^{-1}$ are capable of producing white caps and hence sea-salt aerosol particles (Fitzgerald 1991). In a modeling study, Erickson et al (1986) showed that monsoonal winds can result in sea-salt aerosol mass of over $\left(40 \mu \mathrm{g} \mathrm{m}^{-3}\right)$ over a limited area in the Arabian Sea. In addition to this, the sea-salt loading is also shown to be dependent on not just the wind speed, but also on its variability (standard deviation) as well (Erickson et al 1986). The above discussion suggests that the Arabian Sea under favourable conditions of high wind speeds with large variability is expected to be a major source of sea-salt aerosols.

The peak monsoon (June to August) period with high winds would be expected to have a larger

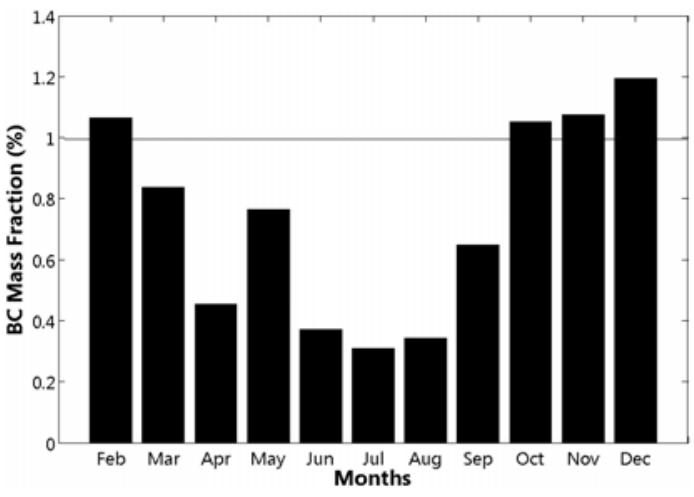

Figure 9. The monthly mean BC mass fraction at Minicoy. (The dark horizontal line shows the $1 \%$ BC mass fraction level.)

mass of super micron aerosols than the winter (DJF) but, the rainfall associated with the monsoon perhaps brings down the sea-salt aerosols by wash out and hence there is a moderate increase in total composite aerosols during the monsoon. Figure 8 clearly shows a slight increase in composite aerosol mass during the peak monsoon months, where most of the increase comes from an increase in the super-micron (mostly sea-salt) aerosols.

\subsection{BC mass fraction}

One of the most important measurement parameters especially from the stand point of radiative forcing is the $\mathrm{BC}$ mass mixing ratio (Babu et al 2004). Based on estimates of aerosol forcing by various species, $\mathrm{BC}$ or soot was found to contribute $6 \%$ to the total aerosol mass, $11 \%$ to the total aerosol optical depth and as large as 35\% to the surface forcing during INDOEX experiment (Satheesh et al 2002). In the present study, the monthly mean $\mathrm{BC}$ and the total aerosol mass were used to obtain the BC mass fraction to the total composite aerosol mass for each month. Figure 9 shows the monthly BC mass mixing ratio for each month. The most striking feature observed is that, though there is seasonality to the BC mass fraction, it is almost always less than $1.2 \%$. During the summer months, the mass fraction drops to as low as $0.3 \%$ of the total aerosol mass loading at surface. Satheesh et al (1999) during INDOEX reported a BC mass fraction of $6 \%$. Babu et al (2004) using ship-borne measurements have shown a large fall in BC mass over the coastal Arabian Sea. They reported a mass fraction of $\sim 2.5 \%$ during March and a drastic fall to $0.5 \%$ during the summer. In addition, Satheesh et al (2006) showed large latitudinal gradient in aerosol characteristics over the Arabian Sea, with soot aerosol optical depth for the latitude band covering Minicoy $\sim 0.04$ and those for regions above $12^{\circ}$ latitude $\sim 0.06$. In the 
present study, we report a BC mass fraction value smaller than those reported earlier. The low value of BC mass fraction reported in conjunction with the earlier observations (Satheesh et al 1999; Babu et al 2004), shows the large seasonality coupled with possible inter-annual variability in aerosol characteristics.

\section{Conclusion}

- Aerosol optical and microphysical measurements were made at a remote island location, Minicoy in southern Arabian Sea from February 2006 to March 2007.

- The Angström exponent varied significantly bringing out the anthropogenic impact (especially during winter period) on the aerosol characteristics.

- The Black Carbon aerosols show large seasonal variation associated with the changing airmass characteristics.

- The seasonality in total mass and super-micron aerosol mass fraction clearly shows the importance of wind speed in modulating the aerosol characteristics, especially during summer.

- The measured BC mass fraction is very low and falls to as low as $\sim 0.3 \%$ during the summer.

\section{References}

Andreae M O, Andreae T W, Ferek R J and Raemdonck H 1984 Long range transport of soot carbon in the marine atmosphere; Sci. Total Environ. 36 73-80.

Blanchard D C 1963 The electrification of the atmosphere by particles from bubbles in the sea; Progress in Oceanography (New York: Pergamon Press) 1 71-202.

Blanchard D C 1983 The production, distribution, and bacterial enrichment of the sea-salt aerosol; In: The air-sea exchange of gases and particles; Liss P S and Slinn W G N (eds) Reidel, p. 407-454.

Bates T S 1999 Preface; J. Geophys. Res. 104(D17) $21,645-21,647$

Bates T S, Anderson T L, Baynard T, Bond T, Boucher O, Carmichael G, Clarke A, Erlick C, Guo H, Horowitz L, Howell S, Kulkarni S, Maring H, McComiskey A, Middlebrook A, Noone K, O'Dowd C D, Ogren J, Penner J, Quinn P K, Ravishankara A R, Savoie D L, Schwartz S E, Shinozuka Y, Tang Y, Weber R J and Wu Y 2006 Aerosol direct radiative effects over the northwest Atlantic, northwest Pacific, and North Indian Oceans: estimates based on in-situ chemical and optical measurements and chemical transport modeling; Atmos. Chem. Phys. 6 1657-1732.

Babu S S, Moorthy K K and Satheesh S K 2004 Aerosol black carbon over Arabian sea during inter monsoon and summer monsoon seasons; Geophys. Res. Lett. 31 L06104, doi:10.1029/2003GL018716.

Bodhaine B A 1995 Aerosol absorption measurements at Barrow, Mauna Loa, and South Pole; J. Geophys. Res. $1008967-8975$.
Cachier H, Buat-Menard P, Fontugne M and Chesslet R 1986 Long-range transport of continentally-derived particulate carbon in the marine atmosphere: Evidence from stable isotope studies; Tellus 38B 161-177.

Clarke A D 1989 Aerosol light absorption by soot in remote environments; Aerosol Sci. Technol. 10 161-171.

Charlson R J, Covert D S and Larson T V 1984 Effect of the humidity on light scattering by aerosols, Hygroscopic Aerosols; Ruhnke L H and Deepak A (eds) (Deepak, Hampton, VA) pp. 35-44.

Draxler R R 1999 HYSPLIT_4 User's Guide, NOAA Tech. Memo ERL ARL-230, June 1999, 35 p.

Eck T F, Holben B N, Dubovik O, Smirnov A, Slutsker I, Lobert J M and Ramanathan V 2001 Column integrated aerosol optical properties over the Maldives during the northeast monsoon for 1998-2000; J. Geophys. Res. 106(D22) 28,555-28,566.

Erickson D J, Merrill J T and Duce R A 1986 Seasonal estimates of global atmospheric sea-salt distributions; J. Geophys. Res. 91(D1) 1067-1072.

Fitzgerald James W 1991 Marine aerosol: A review; Atmos. Environ. 25A(3-4) 533-545.

Haywood J M and Shine K P 1997 Multi-spectral calculations of the direct radiative forcing of tropospheric sulphate and soot aerosols using a column model; Q. J. R. Meteorol. Soc. 123 1907-1930.

Hansen A D A, Rosen H and Novakov T 1984 The aethalometer, an instrument for the real-time measurement of optical absorption by aerosol particles; Sci. Total Environ. 36 191-196.

Hansen A D A 1996 Magee Scientific aethalometer user's guide; 56 pp., Magee Sci. Co., Berkeley, Calif.

Huebert B J, Bates T, Russell P B, Shi G, Kim Y J, Kawamura K, Carmichael G and Nakajima T 2003 An overview of ACE-Asia: Strategies for quantifying the relationships between Asian aerosols and their climatic impacts; J. Geophys. Res. 108(D23) 8633, doi:10.1029/2003JD003550.

Hegg D, Larson T and Yuen P-F 1993 A theoretical study of the effect of relative humidity on light scattering by tropospheric aerosols; J. Geophys. Res. 98(D10) 18,435-18,440, 10.1029/93JD01928.

Im J S et al 2001 An assessment of hygroscopic growth factors for aerosols in the surface boundary layer for computing direct radiative forcing; J. Geophys. Res. 106 20,213-20,224

Ichoku C et al 2002 Analysis of the performance characteristics of the five-channel Microtops II Sun photometer for measuring aerosol optical thickness and precipitable water vapor; J. Geophys. Res. 107(D13) 4179, doi:10.1029/2001JD001302.

IPCC (Intergovernmental Panel on Climate Change) 2001 Radiative forcing of climate change; In: Climate Change 2001 (New York: Cambridge Univ. Press).

Kaufman Y J, Tanre D and Boucher O 2002 A satellite view of aerosols in climate system; Nature $\mathbf{4 1 9}$ 215-223.

Lewis E R and Schwartz S E 2004 Sea Salt Aerosol Production - Mechanisms, Methods, Measurements, and models; Geophysical Monograph Series 152 (Washington: American Geophysical Union), 413 pp., ISBN: 0-87590-417-3.

Monahan E C, Spiel D E and Davidson K L 1986 A model of marine aerosol generation via whitecaps and wave disruption; Oceanic Whitecaps and their Role in AirSea Exchange, Monahan E C and Mac Niocaill G (eds) D. Reidel, 167-174.

Moorthy K K, Satheesh S K and Murthy B V K 1997 Investigations of marine aerosols over tropical Indian Ocean; J. Geophys. Res. 102 18,827-18,842. 
Moorthy K K, Satheesh S K and Murthy B V K 1998 Characteristics of spectral optical depths and size distributions of aerosols over tropical oceanic regions; J. Atmos. Sol. Terr. Phys. 60(10) 981-992.

Moorthy et al 1999 Aerosol Climatology over India; 1 - ISRO GBP MWR network and data base, ISRO GBP SR-0399.

Moorthy K K and Satheesh S K 2000a Characteristics of aerosols over a remote island, Minicoy in the Arabian Sea: Optical Properties and Retrieved Size Distributions; Q. J. Roy. Met. Soc. 126 81-109.

Moorthy K K and Satheesh S K 2000b Aerosol Characteristics over Minicoy: Evidence of Influence of Mineral Dust Transport; J. Mar. Atmos. Res. 2 25-31.

Moorthy K K and Babu S S 2006a Aerosol black carbon over Bay of Bengal observed from an island location, Port Blair: Temporal features and longrange transport; J. Geophys. Res. 111 D17205, doi:10.1029/2005JD006855.

Moorthy K K, Satheesh S K and Suresh Babu S 2006b ICARB: an integrated campaign for aerosols, gases, and radiation budget over India; Proc. SPIE, Vol. 6408, 64080 (November 28, 2006).

Morys M, Mims F M, Hagerup S, Anderson S E, Baker A, Kia J and Walkup T 2001 Design, calibration, and performance of MICROTOPS II handheld ozone monitor and Sun photometer; J. Geophys. Res. 106 14,573-14,582.

Nair S K, Rajeev K and Parameswaran K 2003 Wintertime regional aerosol distribution and the influence of continental transport over the Indian Ocean; J. Atmos. Solar Terres. Phys. 65(2) 149-165.

Porter J N, Miller M, Pietras C and Motell C 2001 Ship based Sun photometer measurements using Microtops Sun photometer; J. Atmos. Oceanic Technol. 18 744-765.

Ramanathan V, Crutzen P J, Lelieveld J, Mitra A P, Althausen D, Anderson J, Andreae M O, Cantrell W, Cass G R, Chung C E, Clarke A D, Coakley J A, Collins W D, Conant W C, Dulac F, Heintzenberg J, Heymsfield A J, Holben B, Howell S, Hudson J, Jayaraman A, Kiehl J T, Krishnamurti T N, Lubin D, McFarquhar G, Novakov T, Ogren J A, Podgorny I A, Prather K, Priestley K, Prospero J M, Quinn P K, Rajeev K, Rasch P, Rupert S, Sadourny R, Satheesh S K, Shaw G E, Sheridan P and Valero F P J 2001 Indian Ocean experiment: An integrated analysis of the climate forcing and effects of the great Indo-Asian haze; J. Geophys. Res. 106(D22) 28,371-28,398, doi:10.1029/ 2001JD900133.

Remer L A, Tanre D, Kaufman Y J, Ichoku C, Mattoo S, Levy R, Chu D A, Holben B, Dubovik O and Smirnov A 2002 Validation of MODIS aerosol retrieval over ocean; Geophys. Res. Lett. 29(12) 8008, doi:10.1029/2001GL013204.

Reddy M S, Boucher O, Venkataraman C, Verma S, Léon J-F, Bellouin N and Pham M 2004 General circulation model estimates of aerosol transport and radiative forcing during the Indian Ocean Experiment; J. Geophys. Res. 109 D16205, doi:10.1029/2004JD004557.

Russell P B, Hobbs P V and Stowe L L 1999 Aerosol properties and radiative effects in the United States east coast haze plume: An overview of the Tropospheric Aerosol Radiative Forcing Observational Experiment (TARFOX); J. Geophys. Res. 104(D2) 2213-2222.

Russell P B and Heintzenberg J 2000 An overview of the ACE-2 clear sky column closure experiment (CLEARCOLUMN); Tellus, Ser. B 52(2) 463-483.

Satheesh S K and Ramanathan V 2000 Large differences in the tropical aerosol forcing at the top of the atmosphere and Earth's surface; Nature 405 60-63.

Satheesh S K, Ramanathan V, Holben B N, Moorthy K K, Loeb N G, Maring H, Prospero J M and Savoie D 2002 Chemical, microphysical, and radiative effects of Indian Ocean aerosols; J. Geophys. Res. 107(D23) 4725, doi:10.1029/2002JD002463.

Satheesh S K and Krishna Moorthy K 2005 Radiative Effects of Natural Aerosols: A Review; Atmos. Environ. 39(11) 2089-2110 APR.

Satheesh S K, Krishna Moorthy K, Kaufman Y J and Takemura T 2006 Aerosol optical depth, physical properties and radiative forcing over the Arabian Sea; Meteorol. Atmos. Phys. 91 45-62.

Shaw G E, Regan J A and Herman B M 1973 Investigations of atmospheric extinction using direct solar radiation measurements made with a multiple wavelength radiometer; J. Appl. Meteorol. 12 374-380.

Vinoj V and Satheesh S K 2003 Measurements of aerosol optical depth over Arabian Sea during summer monsoon season; Geophys. Res. Lett. 30(5) 1263, doi:10.1029/2002GL016664

Vinoj V, Babu S S, Satheesh S K, Moorthy K K and Kaufman Y J 2004 Radiative forcing by aerosols over Bay of Bengal region derived from ship-borne measurements and MODIS optical depths; J. Geophys. Res. 109 D05203, doi:10.1029/2003JD004329.

Verma S, Venkataraman C, Boucher O and Ramachandran S 2007 Source evaluation of aerosols measured during the Indian Ocean Experiment using combined chemical transport and back trajectory modeling; J. Geophys. Res. 112 D11210, doi:10.1029/2006JD007698.

Warneck P 1998 Chemistry of the natural atmosphere; International Geophysics Series 41757 p. (San Diego: Academic Press). 